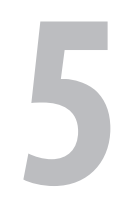

\title{
Cordage from Rapan archaeological sites
}

\author{
Judith Cameron \\ Department of Archaeology and Natural History, The Australian National University, Canberra, Australia, \\ judith.cameron@anu.edu.au
}

\section{Introduction}

More than 80 per cent of the items of material culture produced by traditional Polynesian groups were made from plant fibres (Kirch and Green 2001:164-165), yet very little is known about prehistoric fibre artefacts in French Polynesia. The first Europeans to discover Rapa in 1791 (Chapter 2) exchanged iron for Rapan artefacts, some of fibre. Among them was a fishing line from the Vancouver Collection of the British Museum (Chapter 2). During his fieldwork on Rapa (1920-21), Stokes (n.d.) found several fragments of archaeological cordage on Rapa, but they were all surface finds of unknown age. An assemblage of securely provenanced fibre artefacts was recovered during the 2002 excavations on Rapa. Here, the species of plants used are identified, functional attributes of the specimens in the assemblage are described, function is inferred, and the artefacts are compared with examples from other parts of Polynesia.

\section{The assemblage}

Although dampness and humidity destroy archaeological textiles (a generic term for cordage, matting, basketry, textiles), the Rapan fragments were well-preserved for two reasons: relatively cooler and drier conditions than occur in tropical Polynesian islands, and stratigraphic contexts in dry sand, notably at Tangarutu. The assemblage consists of 19 fragments of worked fibres (Figure 5.1), 17 from Tangarutu and two from Akatanui. The functional attributes of the fragments (Table 5.1) include form, material composition, number and width of individual elements, length and width of grouped elements, numbers and angles of crossing. The number of crossings per $100 \mathrm{~mm}$ was documented as a measure of tightness and strength.

\section{Form of cordage}

The simplest cordage has two strands of the same material composition, diameter and twist. Elaborations are generated by increasing the number of strands, varying the direction of the twists ( $S$ and $Z$ ), employing elements of unequal diameter or altering the construction process by including knots, loops, or other elements (Hurley 1979). The cordage in the Rapan assemblage is of three different types: twisted, braided and knotted. Both twisting and braiding are techniques that increase the tensile strength and durability of fibres, whereas knotting 


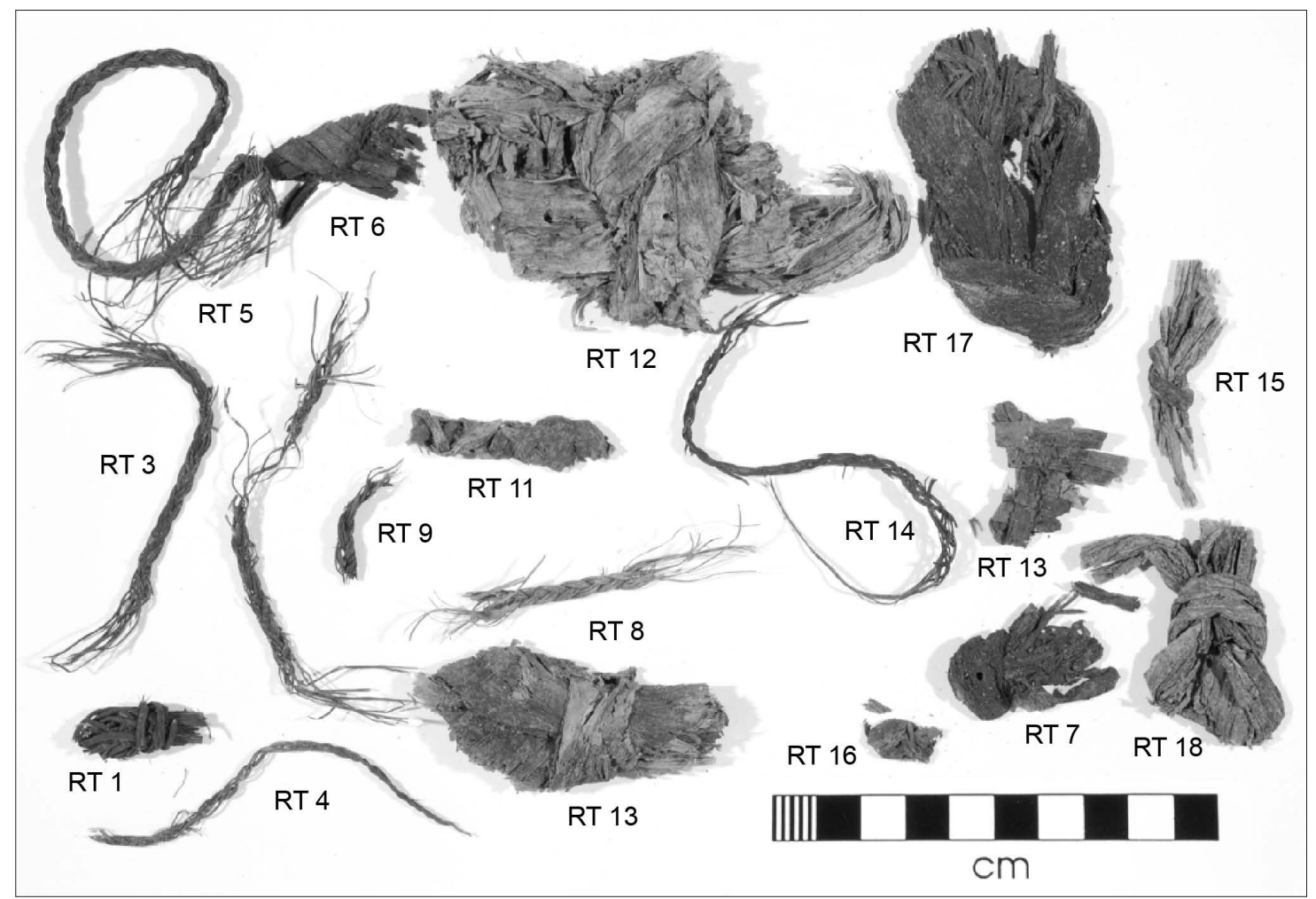

Figure 5.1. Assemblage of fibre artefacts from Tangarutu and Akatanui. See Table 5.1 for information about each item.

Table 5.1. Functional attributes of fibre artefacts from Tangarutu (RT) and Akatanui (RA).

\begin{tabular}{|c|c|c|c|c|c|c|c|c|c|c|}
\hline Number & Location & Form & $\begin{array}{l}\text { Material } \\
\text { composition }\end{array}$ & $\begin{array}{l}\text { Length } \\
(\mathrm{mm})\end{array}$ & $\begin{array}{l}\text { Width } \\
(\mathrm{mm})\end{array}$ & $\begin{array}{l}\text { Width of single } \\
\text { element (mm) }\end{array}$ & $\begin{array}{l}\text { Number of } \\
\text { elements }\end{array}$ & $\begin{array}{l}\text { Number of } \\
\text { crossings }\end{array}$ & $\begin{array}{l}\text { Crossings } \\
\text { per } 100 \mathrm{~mm}\end{array}$ & $\begin{array}{l}\text { Angle } \\
\text { of crossing }\end{array}$ \\
\hline RT 1 & E1 Spit 1 & twisted cordage & Hibiscus sp. & 50 & 6 & 1.2 & 4 & $\mathrm{n} / \mathrm{a}$ & $\mathrm{n} / \mathrm{a}$ & 50 \\
\hline RT 2 & E1 Spit 2 & braided cordage & Freycinetia sp. & 230 & 4 & 1.2 & 3 & $n / a$ & n/a & 60 \\
\hline RT 3 & E1 Spit 2 & braided cordage & Freycinetia sp. & 110 & 4 & 1.1 & 3 & 6 & 5 & 60 \\
\hline RT 4 & E1 Spit 2 & braided cordage & Freycinetia sp. & 95 & 3 & 1.0 & 3 & 11 & 12 & 65 \\
\hline RT 5 & E1 Spit 2 & braided cordage & Freycinetia sp. & 140 & 3 & 1.0 & 3 & 15 & 11 & 60 \\
\hline RT 6 & E1 Spit 2 & braided cordage & Freycinetia sp. & 41 & 2 & 6.0 & & 1 & 0.5 & $\mathrm{n} / \mathrm{a}$ \\
\hline RT 7 & E2 Spit 3 & braided cordage & Freycinetia sp. & 170 & 8 & 8.0 & 3 & $?$ & $\mathrm{n} / \mathrm{a}$ & $\mathrm{n} / \mathrm{a}$ \\
\hline RT 8 & E2 Spit 3 & knotted fibre & B. papyrifera & 70 & 19 & 19.0 & 1 & 2 & 3 & $\mathrm{n} / \mathrm{a}$ \\
\hline RT 9 & E2 Spit 3 & braided cordage & Freycinetia sp. & 25 & 4 & 1.1 & 3 & 3 & 12 & 65 \\
\hline RT11 & E1 Spit 2 & twisted cordage & Hibiscus sp. & 44 & 9 & 4.0 & 3 & 2 & 4 & 50 \\
\hline RT 12 & E1 Spit 1 & knotted cordage & B. papyrifera & 115 & 4 & 1.1 & 3 & 1 & $\mathrm{n} / \mathrm{a}$ & $\mathrm{n} / \mathrm{a}$ \\
\hline RT 13 & E1 Spit 1 & knotted cordage & B. papyrifera & 14 & 10 & 4.5 & 2 & 1 & $\mathrm{n} / \mathrm{a}$ & 60 \\
\hline RT14 & E2 Spit 2 & braided cordage & Freycinetia sp. & 115 & 4 & 1.2 & 3 & 7 & 6 & 65 \\
\hline RA 15 & C1 Spit 3 & knotted fibre & B. papyrifera & 35 & 20 & 6.0 & $?$ & $\mathrm{n} / \mathrm{a}$ & $\mathrm{n} / \mathrm{a}$ & $\mathrm{n} / \mathrm{a}$ \\
\hline RA 16 & C1 Spit 2 & knotted fibre & B. papyrifera & 48 & 5 & 5.0 & 1 & 2 & 4 & $\mathrm{n} / \mathrm{a}$ \\
\hline RT 17 & E1 Spit 3 & knotted fibre & B. papyrifera & 35 & 20 & & & 4 & 12 & $\mathrm{n} / \mathrm{a}$ \\
\hline RT 18 & E1 Spit 3 & knotted fibre & B. papyrifera & 95 & 9 & 4.0 & 2 & 3 & 3 & $\mathrm{n} / \mathrm{a}$ \\
\hline RT 19 & E2 Spit 1 & braided cordage & Freycinetia sp. & 110 & 3 & 1.2 & 3 & 5 & 5 & 65 \\
\hline RT 20 & E2 Spit 1 & braided cordage & Freycinetia sp. & 85 & 4 & 1.2 & 3 & 3 & 4 & 65 \\
\hline
\end{tabular}

*Note: RT10 is not included. Microscopic analysis revealed it was actually an unworked piece of gourd. RT 19 and RT 20 are not shown in Figure 5.1. 
generally increases length. All specimens are small and fragmentary with no use-wear patterns, dyes, or stains discernible.

The two twisted fragments (RT1 and RT11) consist of more than two strands of hard, outer fibres. Although RT11 is defined as twisted cordage, strictly speaking it is simply wrapped. The core element of RT11 is rigid, with untwisted fibre wrapped around the core, a twig. The single elements of this three-stranded cordage measured $4 \mathrm{~mm}$ in diameter. The cord is not wrapped at right angles, but in a helix spiralling from the lower left to the upper right, at regular intervals. The cord would first have been attached to the twig, then wrapped continuously in an oblique way until reaching the end of the twig, then reversed and wrapped in the opposite direction, crisscrossing and overlapping the first layer cord six times, with greater density at one end. The function of RT11 is not indicated by context, but this technique was often used in west Polynesian coiled basketry. Coiling is a basketry technique where active, flexible elements are wound around passive, stationary elements called the foundation. Successive circuits of the foundation are bound together by wrapping. The same technique was also used to make other artefacts such as the cordage used in the fishing device from the Vancouver Collection (Chapter 2) and some small fish hooks from Rapa that may also be from the Vancouver Collection (Figure 5.2), although that is not certain.

RT1 is the end piece of a fibre artefact showing an elaboration of the twisting technique evidenced in RT11. RT1 was worked using four individual strands, each single element measuring $1.2 \mathrm{~mm}$ in diameter. As with RT11, a stick forms the base, but instead of using a single unspun, untwisted element for spiral wrapping, a number of semi-rigid fibre strands are wrapped around the stick over the end, with four strands used to bind the cordage.

Ten of the fragments (RT2, RT3, RT4, RT5, RT6, RT7, RT9, RT14, RT19, RT20) in the assemblage were flat, constructed by braiding. In the early contact literature, the term sennit or sinnet was often used for braided coconut cordage and warp-woven tapes. Braiding is a process derived from diagonal plaiting which produces cordage (and textiles) that is invariably greater in length than width. Braiding can be either two-dimensional with odd or even sets of strands, or three-dimensional forms (tubular and compact), including looped, interlooped, interlinked and knotted structures (Emery 1980:60).

None of the individual elements of the braided cordage in the assemblage had been previously twisted or spun. The commencement point of cordage is generally culturally determined, but this feature could not be ascertained, as the archaeological pieces were fragmentary. The absence of wooden stick fixtures at the site suggests that the braided cordage was probably worked with loose ends. All fragments were worked from flexible fibres and shared the same basic configuration. Six of the fragments were constructed using three strands, called three-ply braiding; one is fourply. The three-ply braids were plaited by passing the elements in the right-hand strand over those in the middle strand, then by reversing the process. During construction, the terminal elements were folded back on themselves at angles ranging from $60^{\circ}$ to $65^{\circ}$ and replaited into the body of each band. The angle of crossing shows a high degree of standardisation. The number of crossings per $100 \mathrm{~mm}$ indicates the tightness of the cordage: the greater the number of twists, the stronger the cordage. Most of the braided cordage in the assemblage was tightly worked, with measurements ranging from $>10$ crossings per $100 \mathrm{~mm}$, with a few examples of loosely plaited forms of $<5$ per $100 \mathrm{~mm}$. Some fragments exhibit 2/1/2 and 2/4/2 shifts.

Seven fragments (RT8, RT12, RT13, RA15, RA16, RT17 and RT18) in the assemblage were knotted. The knot in RT17 is a basic overhand knot, formed by pulling one end through a simple loop. As the fragment is incomplete, its function is unclear. The longest knotted fragments (RT16, RT18), measuring $4.4 \mathrm{~cm}$ in length, were found at Akatanui (Table 5.1). Other types 


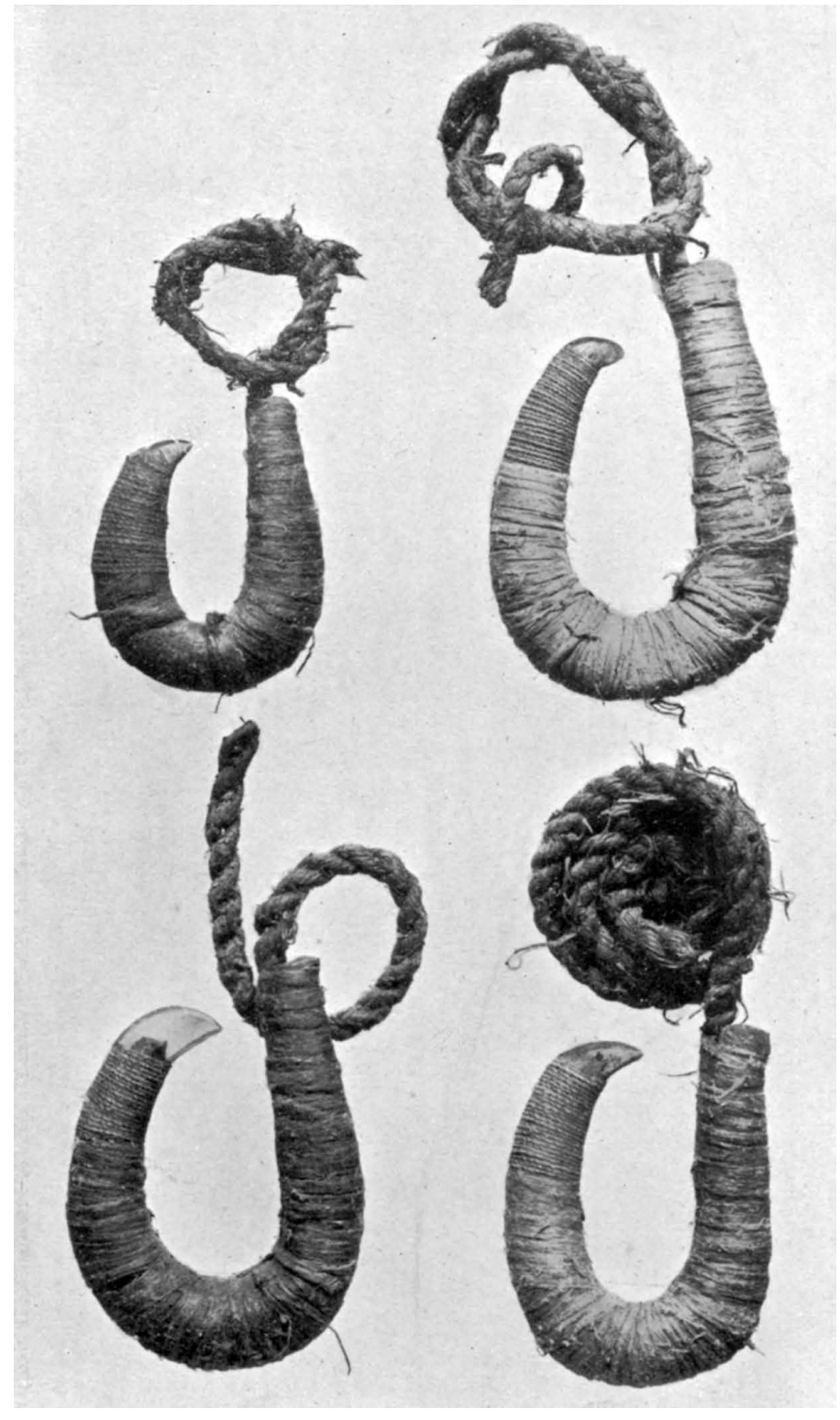

Figure 5.2. Fishing hooks collected from Rapa Island. In the British Museum (Beasley 1928:Plate LXIII; 037 BM). It is not clear whether these were in the Vancouver Collection. All appear to have wood or candlenut shanks, fully bound, but the example at lower left seems to have a shell or bone tip inserted into the shank.

of knotted cordage in the assemblage are more complex and give better insights into function. RT16 is an example of a slightly more complicated knot, the sheet bend, which is still widely used for fishing nets throughout Polynesia.

\section{Material composition}

Identifications by M. Prebble (pers. comm.) indicate that the knotted cordage was made from Broussonetia papyrifera (paper mulberry), the braided cordage appears to have been worked from the roots of Freycinetia spp. (kiekie vine) and the twisted cordage was worked from Hibiscus spp. (purau or hau). While Cocos nucifera (coconut) fibre is not in the archaeological assemblage, Stokes (n.d.) identified coconut fibre cordage, but this might have been from material of 19th century origin, or identified wrongly. Altogether, 37 per cent of the cordage in the Rapan assemblage was made from Broussonetia papyrifera, a fibre introduced by early Polynesians primarily for tapa. The bast would have been removed from the outer bark and dried in the sun before being cut into workable strips. All the $B$. papyrifera fibres were knotted, with individual strips ranging from $1.1 \mathrm{~mm}$ to $20 \mathrm{~mm}$ in diameter. The largest was made from a single strip of 
the plant; most were multiple strips of one to three strands. In the Rapan assemblage, 10 per cent of the cordage was made from Hibiscus spp. In the Society Islands, hau is the term for the bast and more for the cordage from hibiscus. The beach hibiscus is pantropic in distribution, deposited originally by seawater-dispersed seeds (Whistler 1991:65). More than half, 52 per cent, of the cordage in the Rapan assemblage appears to be made of roots from Freycinetia spp. (kiekie). All worked examples of this fibre were braided.

\section{Archaeological comparisons}

All of the cordage types in the Rapan assemblage have been recovered also in surface deposits in caves or from stratified sequences in Hawaii (Kirch 1979; Burney and Kikuchi 2006) and New Zealand (Goulding 1971; Lawrence 1989; Anderson et al. 1991; McAra 2004). The most common cordage in the Pacific archaeological record is aha (Cocos nucifera). It comprises $49 \%$ of the cordage in the B.P. Bishop Museum's archaeological collections (Summers 1990). Of the 98 examples of twisted aha cordage in the Bishop Museum collection, 87 are two-ply of remarkably uniform diameter $(0.8-1.5 \mathrm{~mm})$. Throughout Hawaii, the primary function of twisted aha cordage was for nets (Summers 1990).

Braid is the dominant cordage type in the Bishop Museum's archaeological collection. On Rapa and other Polynesian islands, men were responsible for braiding to produce cordage, whereas women were responsible for twisting cordage and for making bark cloth. Most Hawaiian braid was untwisted and three-ply, but five-ply and seven-ply braided cords (B.P. Bishop Museum:4755, 4756, 4749, 6870) were used to lash canoe hulls to outrigger booms (iako). The width of the cordage in the Bishop Museum ranged from $4.8 \mathrm{~mm}$ to $5.4 \mathrm{~mm}$, whereas the three-ply cordage from Rapa measured between $3.0 \mathrm{~mm}$ and $4.0 \mathrm{~mm}$. Four of the seven hafted adzes in Cook expedition collections are lashed with braided three-ply aha cordage (Kaeppler in Summers 1990:88).

On Rapa, Stokes (n.d.:294) found several pieces of nape kiekie (Freycinetia spp.), with a piece of coir cordage attached to canoe boards in a burial cave at Akatanui. Stokes observed that $k a^{\prime} a$, the original Rapan name for this type of cordage, was slowly being replaced by nape, the Tahitian term for braid. According to Stokes, nape from kiekie was said to be fairly durable but did not last as long as coir cordage. Braid was also a component of the close-meshed kiekie fishing baskets (inaki) woven on Rapa using the twining technique (Plate 8442). Kiekie baskets from Rapa were in demand in Tahiti and Mangareva. Stokes (n.d.) also recorded wide-meshed war nets, woven, probably, from kiekie.

Precisely the same technique was used to work a fragment of tightly braided three-ply $u k i$ uki (Dianella sp.) cordage recovered from a burial site (designated 1985.669.013) in Kohala, Hawaii (Summers 1990). Stokes (n.d.:Plates 8550, 8551) found decayed woven fragments (Plates 8550 and 8551 ), identified as mortuary cloaks, in some Rapan rockshelters. His descriptions of cloaks indicate that warps were made of rigid fibres from the giant rush, Scirpus spp., placed in parallel rows manipulated by the weaver's feet. The soft, pliable wefts, made from twisted bast fibres, such as more from Hibiscus tiliaceus, or raupo from Typhus spp., were worked at right angles. The wefts created a soft pile regarded by Rapans as good for cold weather. (Stokes n.d.). The closedtwining technique was also used for $t i$ (Cordyline spp.) kilts. While twined fish baskets were widespread throughout Polynesia (Burrows 1970:26), twined kilts did not occur in western Polynesia, being confined to the Tuamotus and Rapa. Short lengths of braided Freycinetia spp. cordage were attached to cloaks and mortuary robes for fastening. Stokes compared Rapan cloaks with New Zealand equivalents and found Rapan forms to be similar, but less refined. Cloaks held considerable social and ritual significance throughout Polynesia and Ellis' informant, 
Teraau, explained the colour symbolism of Rapan cloaks. Royal cloaks incorporated dark blue feathers from kotokoto birds (species unknown, but possibly the Tuamotuan kingfisher, Halcyon gambieri (SOPF 1999:41), the feathers of which were probably imported in the European era), whereas those intended for commoners were made from black and white petrel feathers.

New Zealand excavations have also produced fragments of mortuary cloaks and cordage. Lawrence (1989) recovered cordage during excavations of a historical site in the Waitakere Ranges, and Lander (1992) similar material from Raupa. Anderson et al. (1991) found numerous fragments of harakeke (Phormium tenax) cordage during excavations at Fiordland, and also a piece of a woven harakeke and bird-feather cloak. Harakeke netting and cordage fragments were also reported from waterlogged contexts at the late Maori village of Kohika (McAra in Irwin 2004) and from a cave on the Banks Peninsula (McAra in Irwin 2004).

\section{Conclusions}

The main sources of cordage on Rapa were the fibrous roots and vines of native kiekie and the introduced paper mulberry, with a small proportion of samples from hibiscus. While some coconut-fibre artefacts might have been collected by Stokes, no coconut fibre occurs in the excavated samples, and this is consistent with the probable absence of coconut until the historical era.

Given the multiple uses of cordage, it is difficult to determine the function of examples in the Rapan assemblage. However, as most of the material came from Tangarutu cave, which had functioned very largely as a fishing station, it is most likely that the fibre artefacts were associated with that activity. The cord-wrapped stick from Tangarutu could either be the handle of a fishing basket or part of a fishing line, with the softer bast elements wrapped around the rigid elements to protect the user's hands. The knotted aute cordage compares favourably with archaeological aute from Hawaii identified as carrying bags and nets. The absence of twisting suggests the Rapan samples are probably the remains of nets. The braided cordage in the assemblage seems most likely to have been the remains of a longer length of cordage used for fishing lines or nets. 


\section{References}

Anderson, A., Goulding, J. and White, M. 1991. Bark and fibre artefacts. In: Anderson, A.J. and McGovern-Wilson, R. (eds), Beech Forest Hunters: the archaeology of Maori rockshelter sites on Lee Island, Lake Te Anau, in southern New Zealand, pp. 43-55. New Zealand Archaeological Association, Auckland.

Beasley, H.G. 1928. Pacific Island Records: Fish Hooks. Seeley Service, London.

Burney, D. and Kikuchi, W.P. 2006. A Millennium of human activity at Makauwahi Cave, Maha’ulepu, Kaua’i. Human Ecology 34:219-247.

Burrows, E.C. 1970. Western Polynesia: a study of cultural differentiation. University Book Shop, Dunedin. Emery, I. 1980. The Primary Structures of Fabrics. The Textile Museum, Washington.

Goulding, J. 1971. Identification of archaeological and ethnographical specimens of fibre-plant material used by the Maori. Records of the Auckland Institute and Museum 8:57-101.

Hurley, W.M. 1979. Prehistoric Cordage: identification of impressions on pottery. Taraxacum, Washington. Irwin, G. 2004. Kohika: The Archaeology of a late Maori lake village in the Ngati Awa rohe, Bay of Plenty, New Zealand. Auckland University Press, Auckland.

Kirch, P. 1979. Marine Exploitation in Prehistoric Hawaii. Pacific Anthropological Record 29. Bernice P. Bishop Museum, Honolulu, Hawaii.

Kirch, P. and Green, R. 2001. Hawaiki: Ancestral Polynesia: An Essay in Historical Anthropology. Cambridge University Press, Cambridge.

Lander, M. 1992. Fibre fragments from the Raupa site, Hauraki Plains. Records of the Auckland Institute and Museum 29:7-23.

Lawrence, J. 1989. The Archaeology of the Waikakere Ranges. Unpublished MA thesis, University of Auckland.

McAra, S. 2004. Kohika fibrework. In: Irwin, G. (ed), Kohika: The Archaeology of a late Maori lake village in the Ngati Awa rohe, Bay of Plenty, New Zealand, pp. 149-159. Auckland University Press, Auckland.

Stokes, J.F. n.d. Ethnography of Rapa. Manuscript in the Bernice P. Bishop Museum Collection, Honolulu, Hawaii.

Summers, C. 1990. Hawaiian Cordage. Bernice P. Bishop Museum, Honolulu, Hawaii.

Whistler, W.A. 1991. Polynesian plant introductions. In: Cox, P.A. and Banack, S.A. (eds), Islands, Plants and Polynesians: an introduction to Polynesian ethnobotany, pp. 41-66. Dioscorides Press, Portland, Oregon. 